\title{
Immune Blockade Inhibition in Breast Cancer
}

\author{
IOANNIS A. VOUTSADAKIS \\ Division of Medical Oncology, Department of Internal Medicine, Sault Area Hospital and \\ Division of Clinical Sciences, Northern Ontario School of Medicine, Sudbury, ON, Canada
}

\begin{abstract}
Besides limited success in treatment of melanoma and renal cell carcinoma, immune treatments of cancer (cancer immunotherapy) had not until recently met the great expectations associated with them over the years. This failure appears now to be reversed with the introduction of checkpoint (immune blockade) inhibitors. Two receptor-ligand checkpoint inhibition pairs, the one based on the inhibition of inhibitory receptor cytotoxic T lymphocyte-associated antigen 4 (CTLA-4) and the other based on the inhibition of the programmed death-ligand 1/programmed cell death-1 (PD-L1/PD-1) pair have entered the clinical arena. Melanoma leads the way followed by non-small cell lung cancer (NSCLC) in both of which such drugs are already approved for clinical use. Several other cancer types will follow as trials data accumulate. Breast cancer clinical data are mixed so far and the arising picture is one of efficacy dependent on sub-types and sub-sets. This article will review available data on checkpoint molecules expression in breast cancer cells that may be one determinant factor of effective inhibition, as well as other possible biomarkers of immune blockade inhibitors effectiveness in breast cancer. Emerging data of clinical trials of immune checkpoint inhibitors in breast cancer will also be presented. Development and validation of reliable predictive markers of response to this new category of anti-cancer drugs will help optimize results and spare patients not expected to respond the toxicity and cost of the drugs. Moreover, predictive markers may advance the understanding of resistance to these therapies in order to reverse it.
\end{abstract}

This article is freely accessible online.

Correspondence to: Ioannis A. Voutsadakis, MD, Ph.D., Division of Medical Oncology, Sault Area Hospital, 750 Great Northern Road, Sault Ste Marie, ON P6B 0A8, Canada. Tel: +1 7057593434 , Fax: +1 7057593815, e-mail: ivoutsadakis@yahoo.com or ivoutsadakis@nosm.ca

Key Words: Immune blockade, checkpoint inhibition, breast cancer, PD1, PD-L1, CTLA-4, tumor infiltrating lymphocytes, biomarkers, review.
Breast cancer has been the solid tumor that led the way of targeted treatments, building on the early characterization of clinical and later molecular sub-types. Identification of estrogen receptor (ER)-positive and -negative sub-sets formed the basis for the success of targeted hormonal therapies initially with tamoxifen and later with aromatase inhibitors (1). Breast cancer was also the first solid tumor treated with a monoclonal antibody, trastuzumab, for the Her2-positive sub-set, that is still probably the most successful monoclonal antibody treatment in solid tumor oncology and has changed the natural history of Her2positive disease $(2,3)$. Therapeutic improvements based in these targets either with introduction of additional drugs or extension of treatment with existing drugs are still forthcoming $(4,5)$. Nevertheless, there exist sub-types of breast cancer where targeted treatment options have not been so successful or are non-existent. These include the so called triple-negative cancers and the luminal B ERpositive, Her2-negative cancers that are less sensitive to hormonal manipulations than the luminal A counterparts. At least part of the therapeutic targeting problem in these cancers stems from the fact that these types of breast cancers are heterogeneous and, thus, lack a unifying target. This is clear for triple-negative cancers, for example, which can be divided molecularly to several further subtypes (6, 7). The subtype that possesses breast cancer (BRCA)1/BRCA2 mutations or BRCA-related functional deficits (so called BRCAness) is particularly sensitive to poly ADP ribose polymerase (PARP) inhibitors, as BRCA deficits are synthetically lethal with PARP inhibition (8). There is a need for improved treatments for both triplenegative and luminal $\mathrm{B}$ cancers, as well as luminal $\mathrm{A}$ and Her2-positive cancers that become resistant to currently approved targeted therapies.

The immune system has been viewed for decades (if not for centuries given that Hippocrates wrote for forces within the body in neutralizing disease) as an invaluable ally in the fight against cancer, despite the fact that, except in very specific cases, attempts to harness its anti-cancer potential 
have been met with minimal success mainly in a minority of melanoma and renal carcinoma patients. This seems to be changing with the introduction of immune blockade inhibitors in various cancers. Immune blockade inhibitors (also called immune checkpoint blockers) may represent novel therapies addressing the unmet need of therapy in breast cancers resistant to current treatments or for which no current targeted treatments exist. These treatments, their biology and biomarkers to guide their development will be discussed in this paper.

\section{Immune Blockade Basic Biology}

In contrast to other monoclonal antibody therapies used currently in oncology that block receptors expressed on the surface of tumor cells, such as Her2 or epidermal growth factor receptor (EGFR), monoclonal antibodies blocking immune receptors bind receptors on immune cells or their ligands that are expressed on both immune and tumor cells. In this regard, immune blockade blockers are more reminiscent of the monoclonal antibody bevacizumab that binds the ligand vascular endothelial growth factor (VEGF) whose receptor, VEGFR, is expressed by both tumor cells and endothelial cells of the tumor microenvironment. In contrast to all other currently used monoclonal antibodies in oncology, both the ligand and receptor pair targets of immune blockers are expressed on the surface of cells, although soluble forms exist.

Activation of immune cells requires ligation of the antigen presentation receptor TCR ( $\mathrm{T}$ cell receptor) and concomitant engagement of co-stimulatory receptors. This co-stimulation is of defining importance as witnessed by the fact that if instead of it, a co-inhibitory signal is present, receiving immune cells become anergic and may die (9). In cancers, co-inhibitory signals impede the antineoplastic immune response both at the level of activation of immune effector cells by antigen presenting cells and in the phase of immune recognition of tumor cells by immune effectors. The first step, presentation of antigens by antigen presenting cells (APCs) involves co-stimulatory ligandreceptor pairs, such as OX40L and OX40, CD40L and CD40, 4-1BBL and 4-1BB, as well as CD80/CD86 and CD28 in APCs and effector cells, respectively. If CD80 or CD86 is ligated by cytotoxic $\mathrm{T}$ lymphocyte-associated antigen 4 (CTLA-4; alternatively called CD152) instead of CD28, an inhibitory signal is generated (10). The avidity of CD80 and CD86 ligands for CTLA-4 is several hundred times higher than for CD28 and, thus, the inhibitory signal is favored when both receptors are expressed in the cell surface. A soluble form of CTLA-4 is secreted after lymphocyte activation and has a role in containing the immune response and avoiding perpetuation of response beyond the initial stimulation (11). Other ligand-receptor couples generating inhibitory signals are programmed death-ligand 1 (PD-L1; also known as CD274 or B7H1)/PD-L2 (also called CD272 or B7-DC)- programmed cell death-1 (PD-1; also known as PDCD1 or CD279) and galectin-9/ CEACAM-1- TIM-3 (12).

The second step of immune destruction of cancer cells that involves the synapse of activated immune cells with the target cancer cell may be inhibited by engagement of coinhibitory signals, which, in this step, involve mainly the PD-L1/PD-L2- PD-1 ligand-receptor pairs. CTLA-4 has been additionally detected in tumor cells and may play a role in inhibiting the anti-tumor immune response in this phase, in addition to the activation phase (13). Prerequisites of the second step are avoidance of inhibition in the first step, presence of signals to attract effector cells and infiltrate the tumor microenvironment, avoidance of inhibition in this microenvironment by regulatory $\mathrm{T}$ cells before the engagement with tumor cells and presentation of tumor antigens by the tumor cells in the context of major histocompatibility complex (MHC) class I molecules. If any of these prerequisites is not present the immune system would be unable to mount an effective tumor response. In addition, if the inability to mount a response is due to any other reason besides immune blockade at the presentation or effector synapse, drug treatment with monoclonal immune blockade inhibitors would be predicted to be less effective or ineffective.

\section{Expression of Immune Blockade Molecules in Breast Cancer and Prognosis}

Experience from other targeted therapies, such as hormone therapy and Her2 targeted therapies, have shown that these treatments are only effective when the target is expressed in tumor cells. In other occasions, expression of target is not sufficient to guarantee success of treatment. This is the case for EGFR-directed therapies in colorectal cancer, where activation of pathways down-stream of the receptor due to $K$-ras or other mutations reduce the efficacy of these therapies, even when the target receptor is expressed. In the case also of therapies directed against the VEGFVEGFR ligand-receptor couple, expression of the targets are not markers of response. This is possibly because these proteins interfere with neo-angiogenesis and are expressed in other types of cells, such as endothelial, besides tumor cells, and this expression may be equally or more important for the success of therapy. This is also relevant for immune blockade therapies that have targets expressed in immune effector cells. Nevertheless, expression of the target proteins in both cancer and immune cells is worth investigating as a response marker because, although it may not be a guarantor of response, it may be a prerequisite. 
CTLA-4. CTLA-4 expression in tumor cells and tumor infiltrating lymphocytes (TILs) was examined using a semiquantitative counting method in a retrospective series of breast cancer patients (13). Forty eight of 130 patients (37\%) in this series had a higher intensity CTLA-4 expression in the breast cancer cells using the cut-off established by the authors and 73 of $130(56 \%)$ had a high intensity of CTLA-4 expression in TILs infiltrates. Patients with both a high intensity of CTLA-4 expression in TILs and a low expression of CTLA-4 in breast cancer cells had a statistically significantly better overall and disease-free survival than the rest of the patients (13). Another study employed immunohistochemistry and confirmed the presence of CTLA-4 protein in four different breast cancer cell lines, while two non-tumorigenic cell lines had a lower positivity (14). Expression was also present in breast cancer tissues from patients and included both the invasive and the in situ part of the tumors but not adjacent normal breast epithelium. These data suggest that some tumors up-regulate CTLA-4 expression early in carcinogenesis in the pre-invasive stage. CTLA-4 mRNA expression was increased in peripheral lymphocytes from breast cancer patients compared to healthy controls (15). CTLA-4 mRNA expression increase was correlated with an increase in the expression of FOXP3 mRNA expression, a marker of regulatory $\mathrm{T}$ lymphocytes (Tregs). Higher levels of the soluble form of CTLA-4 were observed in the serum of breast cancer patients compared with healthy controls (16). Thus, it seems that, in many breast cancers, a tumor immune response is triggered, which is subsequently impeded by CTLA-4 expression and Tregs up-regulation.

$P D-L 1 / P D-1$. In breast cancer tissues $P D-L 1$ mRNA expression was detected in 55 to $59 \%$ of cases and correlated with a better recurrence-free survival independently of other known prognostic factors in stage I to III patients (17). $P D$ L1 mRNA positivity was not associated with ER or Her2 status. TILs were evaluated in the same study by a visual semi-quantitative method. Cases positive for TILs represented $16.6 \%$ of total and most (12\%) were positive for $P D-L 1$ mRNA. TILs negative cases were $P D-L 1$ mRNA positive in $46 \%$ and $P D-L 1$ mRNA negative in $37 \%$ of total breast cancers examined. TILs were associated with ERnegative status but were not overall prognostic (17). Another mRNA analysis showed $P D-L 1$ up-regulation (compared to normal breast tissue) in $20 \%$ of breast cancers (18). Upregulation of $P D-L 1$ mRNA was more common in basal and Her-2-enriched sub-types compared to luminal sub-types. In addition, in basal tumors high $P D-L 1$ mRNA expression was prognostic of a better metastasis-free and overall survival, whereas no prognostic value of this expression was observed in the breast cancer cohort as a whole (18).

The locus of $P D-L 1$ and $P D-L 2$ at human chromosome 9p24 was found to be amplified in 12 of 41 (29\%) triple- negative breast carcinomas, but not in any of the 23 ERpositive or Her2-positive carcinomas examined (19). The amplicon, which included also the locus of the JAK2 kinase gene, was confirmed to be translated producing higher levels of mRNA than those observed in non-amplified patients. Patients harboring the amplification of the $P D-L 1$ and $P D$ L2 locus seemed to have tumors with less TILs and a worse prognosis (19).

A genomic study examining the invasive lobular carcinoma histologic sub-type, representing about $10-15 \%$ of total breast cancers, found that these cancers could be classified in two groups, an immune-related and a hormone-related group (20). Cases in the immune-related group displayed high expression of $P D-L 1, P D-1$ and $C T L A-4$ in the mRNA level and were more sensitive to DNA-damaging agents.

An extensive study of PD-L1 protein expression in breast cancer using tissue microarrays found a very low expression of $6 \%$ in TILs and an even lower expression of $1.7 \%$ in tumor cells (21). Basal-like tumors defined genomically or by surrogate triple negativity in immunohistochemistry were more often positive and displayed more often (19\%) an infiltration by PD-L1-expressing TILs. Another study confirmed a higher positivity for PD-L1 in triple-negative carcinomas, which were positive in about $20 \%$ of cases (22). Others have reported PD-L1 expression in both the tumor cells and TILs of breast cancers in $34 \%$ and $41 \%$ of cases respectively (23). ER- and progesterone receptor (PR)negative tumors, as well as Her2-positive ones had a higher PD-L1 positivity. A tissue microarray immunohistochemistry series of 650 breast cancer patients found $23.4 \%$ of patient samples to be positive for PD-L1 in tumor cells (24). Basal and Her-2 overexpressing carcinomas displayed an even higher positivity of $29 \%$ to $34 \%$, consistent with the previous study, while luminal $\mathrm{A}$ and Her2-negative luminal B cancers were PD-L1 positive in $12.1 \%$ and $20.4 \%$ of cases respectively. In multivariate analysis, PD-L1 positivity was associated with a worse overall survival in the entire cohort and the basal subset but not in other sub-types (24). A study of 870 breast cancer patients from China used immunohistochemistry for PD-L1 detection and found positivity in $21.7 \%$ of patients (25). PD-L1 expression was associated with triple-negative tumors, higher grade and size, node positivity and a worse prognosis. Still, another immunohistochemistry study examining both PD-L1 and PD-L2 in 192 stage I to III breast cancer patients showed $56.6 \%$ and $50.8 \%$ to be positive, respectively, and confirmed that positive tumors were more often ER-negative and lymph node-positive (26). Unexpectedly, despite a higher distant recurrence rate in PD-L1 positive patients, their overall survival was better than PD-L1-negative patients, a fact that the authors attributed to a stronger underlying anti-tumor immune response leading to the observed PD-L1 positivity (26). 
Interestingly circulating breast cancer cells from metastatic ER-positive Her2-negative breast cancers express PD-L1 in a higher percentage $(68 \%)$ than that seen in this sub-type of patients discussed above, arguing for increased expression of the molecule along with progressing disease (27). An additional study showed an increase of $P D-L 1$ mRNA expression in peripheral blood cells of breast cancer patients compared with healthy controls (28). Patients with metastatic disease had even higher $P D-L 1$ mRNA expression in their peripheral blood cells than patients with localized disease (28).

A tissue microarray-based immunohistochemistry analysis similar to the one performed for PD-L1 was also undertaken for expression of PD-1 in TILs of breast cancer (29). 15.8\% of the cases were positive for PD-1 TILs. Again, basic-like cancers had the higher positivity rate $(27.3 \%)$, followed by Her-2 positive cancers, while luminal cancers had a lower positivity (4.7\% for luminal A and $12.1 \%$ for luminal B). In the cohort as a whole and the basal-like subset, cases with PD-1-positive TILs had a worse overall survival than patients without PD-1-positive TILs (29).

Overall, most expression studies of immune blockade molecules in breast cancer confirm expression in a significant percentage of patients that is higher in triplenegative and Her2-positive subtypes than in ER-positive cancers (Table I). Regarding prognosis, a high expression of immune blockade molecules in TILs and low expression in cancer cells may be associated with the best survival outcomes. This profile may be associated with an activated immune response. It also appears that there are increases in expression of immune blockade molecules as a tumor progresses from in situ to invasive and then to metastatic.

\section{TILs as a Prognostic Marker and Possible Predictive Marker of Response to Immune Blockade Inhibitors in Breast Cancer}

As described in the previous section, studies have examined the presence of TILs in conjunction with expression of immune blockade molecules given that the two constitute elements of the immune response initiation and subsequent regulation and presence of the immune cells in the tumor microenvironment is thought to be a prerequisite for the mounting of a successful anti-tumoral immune response. Several studies have examined TILs independently of immune blockade molecules as prognostic markers influencing breast cancer outcomes in chemotherapy trials. Increased TILs were an independent good prognostic factor in a meta-analysis of triple-negative breast cancers (30). A meta-analysis of studies examining TILs in early stage triplenegative breast cancer confirmed that increased infiltrates were associated with a better disease-free survival, distant disease-free survival and overall survival (31).
In Her2-positive early breast cancer treated in a phase III trial, a higher number of TILs was predictive of a benefit of trastuzumab treatment (32). Patients with higher numbers of stromal TILs in their tumors had a significant better survival when treated with trastuzumab compared with those having high TILs but no trastuzumab treatment. In patients with low TILs, addition of trastuzumab in their adjuvant chemotherapy treatment did not affect outcome (32). These results argue for an important role of antibody-mediated cytotoxic immune response as a mechanism of trastuzumab action in Her2positive breast cancer. In the overall Her2-positive population in this study, TILs density was not prognostic of distant disease-free survival, while in the triple-negative population TILs were prognostic for this outcome (32).

In a study of TILs in localized triple-negative and Her2positive breast cancers that used a three tier evaluation system in pathologic slides (high TILs $>50 \%$, intermediate $10-50 \%$ and low TILs $<10 \%$ ), a high TILs infiltration was associated with a better prognosis in triple-negative patients treated with adjuvant chemotherapy but not in Her2-positive patients (33). In contrast, high post-treatment TILs had a good prognostic implication after neo-adjuvant treatment in Her2-positive cancers but displayed no statistically significant prognostic value in triple-negative ones. Nevertheless, the four triple-negative patients in the high TILs tier had all remained relapse-free, while eleven of 24 patients in the intermediate and low TILs tiers had relapsed within about 3 years of follow-up (33).

Additional studies in the neo-adjuvant setting were performed and reviewed in a meta-analysis that studied the value of TILs as a predictor of pathologic complete response (pCR) after neo-adjuvant chemotherapy (34). Higher TILs numbers were associated with a better rate of pCR overall and in triple-negative and Her2-positive carcinomas but not in ER-positive cancers. Data from the NeoSphere trial that compared different combinations of neo-adjuvant therapies in Her2-positive breast cancers used a three tier TILs grading system $(<5 \%, 5-50 \%$ and $>50 \%)$ and showed that $14 \%, 69 \%$ and $17 \%$ of cases belonged to the low, intermediate and high TILs categories, respectively (35). In the three arms of the study that neo-adjuvant treatment consisted of doublets of docetaxel, trastuzumab and pertuzumab, the pathologic complete response rate in the breast (pCRB) was lower for the low TILs carcinomas $(4.3 \%)$ than for the intermediate and high TILs carcinomas (26.9\% and $26.4 \%$, respectively). In the triplet arm receiving all three drugs a more balanced pCRB rate was observed $(28.6 \%, 48.9 \%$ and $22.2 \%$ in the low, intermediate and high TILs groups, respectively) (35). A study of anthracycline and taxane-based neo-adjuvant chemotherapy, which included only Her2-negative patients, showed that $36.5 \%$ of ER-negative patients (triple-negative) were lymphocyte-predominant (defined as having more than $60 \%$ TILs), while only $12 \%$ of ER-positive patients had 
Table I. Overview of CTLA-4 and PD-L1/PD-1 expression in breast cancer.

- High expression of CTLA-4 in tumor cells in $37 \%$ of breast cancer cases and in TILs in $56 \%$ of breast cancer cases.

- CTLA-4 expression also observed in associated carcinomas in situ but not adjacent normal breast epithelium.

- Higher expression of CTLA-4 in tumor cells and lower expression in TILs associated with better prognosis.

- PD-L1 expression is observed in about $20 \%$ of all breast cancers and varies with breast cancer sub-type: Higher in triple-negative and Her2positive cancers (30-35\%), less in luminal B cancers ( about 20\%) and least in luminal A cancers (about 10\%).

- PD-L1 expression seems to be associated with adverse prognostic features (higher grade and size and node positivity)

- PD-L1 expression was documented in circulating ER-positive Her2-negative breast cancer cells.

- Prognostic value of PD-L1 expression in breast cancer is not clear and may be confounded by associations with other prognostic factors or expression of other immune modulators.

- PD-1 expression is observed in TILs in about $15 \%$ of breast cancers with the higher expression again in triple-negative cancers followed by Her2positive, luminal B and luminal A cancers in decreasing order of positivity.

Table II. Overview of TILs presence and significance in breast cancer.

- Lymphocyte-predominant (TILs more than 50-60\%) breast cancers represent about 12\%, $18 \%$ and 36\% of ER+, Her2+ and triple-negative cancers, respectively.

- TILs presence is associated with better prognosis in triple-negative and Her2-positive cancers.

- TILs presence is associated with a higher benefit from addition of trastuzumab in Her2-positive cancers.

- Post-neoadjuvant treatment TILs presence is associated with good prognosis in Her2-positive cancers.

- No association of TILs (as a continuous variable) with pathologic response after neoadjuvant treatment in ER-positive cancers.

- Possible association of lymphocyte predominance with complete pathologic response post-anthracycline/ taxane-based chemotherapy in ERpositive cancers.

- Positive correlation of TILs with PD-L1 expression in cancer cells and stroma.

- A possible predictive value of TILs in immune blockade inhibitor therapies efficacy is suggested by their association with triple-negative cancers but remains to be confirmed.

lymphocyte predominance (36). Patients with lymphocyte predominance had a significantly higher percentage of complete pathologic response to neo-adjuvant chemotherapy (36). In another neo-adjuvant study of triple-negative patients who received chemotherapy with or without the antiEGFR antibody panitumumab, patients with higher CD8+ TILs (defined in this study as a TILs count $>118$ ) had an $84 \%$ pCR rate as compared to $10 \%$ in patients with low TILs (37). In addition, a positive correlation of TILs with PD-L1 expression in cancer cells and stroma and with complete pathologic response (pCR) following neo-adjuvant chemotherapy was shown in another study (38). Specific sub-sets predicting for a good pCR rate included CD8+ infiltrates and FOXP3+ but persistence of FOXP3+ TILs after neo-adjuvant treatment was associated with an inferior complete pathologic response rate (34).

The types of immune cells in the tumor microenvironment is equally or even more important than the number of TILs. Effector CD8+ cells are the lymphocytes that, when activated, execute the immune surveillance, while regulatory FOXP3+ lymphocytes are inhibitory and impede immune responses having the physiologic role of preventing excessive activation but in the tumor microenvironment they may act as inhibitors of the anti-tumor response. A study in breast cancer patients showed that higher FOXP3+ and lower CD8+ cell infiltrates in the tumor were associated with metastatic disease to the lymph nodes (39). Nevertheless, despite a negative prognostic value in univariate analysis, multivariate analysis concluded that FOXP3+ TILs had no independent prognostic influence in a series of more than 1,400 breast cancer patients, possibly due to association with other immune cell sub-sets and other prognostic factors (40). Another study of circulating lymphocyte populations reported that the absolute numbers of FOXP3+ cells were not different between breast cancer patients of early or late stages of breast cancer and healthy controls but the total number of CD4+ was lower in patients (41). In another study of neo-adjuvant chemotherapy, yet, patients that responded positively to treatment had a decrease in circulating FOXP3+ lymphocytes, although their levels were not completely normalized (42). CD20+ B cells show also a positive correlation with an improved survival in breast cancer (43). These infiltrates are mostly located at the periphery of the tumors and are, similarly to $T$ cell sub-sets, associated with ER-negative tumors. The periphery of the tumor is also the most common part of the tumor environment where CD8+ T cells are observed and, due to this predominance, they become statistically predictive for a positive prognosis in breast cancer (44).

Overall, available data lead to conclude that TILs have a higher prevalence in triple-negative and Her2-positive breast 
cancers and portend an improved prognosis (Table II). Specific immune cell type of infiltrates may be of importance. In ER-positive cancers, TILs prevalence is lower and it becomes more difficult to confirm their prognostic value. Whether TILs predict indeed for immune blockade inhibitors efficacy in breast cancer remains to be confirmed in the clinical trials under way. Utility of TILs as biomarkers will be greatly improved by establishing consensus criteria for their identification and quantification in clinical practice (45). The fact that triple-negative tumors tend to respond to these drugs in the initial clinical trials as will be discussed in a following section would argue for the value of TILs as predictors of response markers.

\section{Genetic Instability as a Predictor of Immune Blockade Efficacy}

Another predictor of response of an individual tumor to immune blockade inhibition could be its propensity to present neo-antigens, novel antigens derived from mutant or abnormally expressed proteins. Immune CD8+ cells targeting tumor neo-antigens are kept under control inside the tumor site by inhibitory molecules, such as CTLA-4 and PD-L1 (46). The number of CD8+ immune cells bearing a TCR able to recognize a tumor epitope and infiltrating the tumor may be directly related to the number of new mutated proteins that a tumor cell harbors, related in its turn to genetic instability, despite the fact that only a minority of mutations are actually able to produce neo-antigens (47). This has been studied experimentally in colon cancer where there is a wellestablished dichotomy between microsatellite stable and instable cancers (MSS and MSI, respectively). MSI colon cancers are associated with down-regulation of one of the mismatch repair genes, such as MSH2, MSH6, MLH1 and PMS2, producing a high load of mutations and tumor neoantigens that are 10- to 50-times higher than those in MSS cancers (48). These neo-antigens are associated with increased TILs in MSI cancers (49). Nevertheless, TILs are not producing robust immune rejections because of the actions of immune blockade molecules (50). Thus, immune blockade inhibitors have been proposed and are studied as treatment, specifically in MSI colorectal cancers and other mismatch repair deficient cancers. Despite the fact that colorectal cancers overall have shown low rates of response to immune blockade inhibitors, MSI cancers displayed a $40 \%$ response rate and $50 \%$ stability (51). In breast cancer, the incidence of MSI is much lower than the incidence observed in colorectal or endometrial carcinomas and ranges between $1-3 \%$ only $(52,53)$. This is depicted in studies of mutational landscapes across different types of cancers where breast cancer has one of the lowest mutation burden compared with other locations, such as melanoma and lung cancers $(54,55)$. These considerations, though, do not exclude the possibility that a sub-set of breast cancers are immunogenic and may be appropriate for immune blockade treatments. In addition, even a low mutational burden could theoretically be sufficient if presentation of neo-antigens is efficient. In this regard, a study that used an in silico epitope prediction algorithm proposed that both breast and colorectal cancers present an average of seven to ten human leukocyte antigen (HLA)-A*0201-associated neo-antigens (56). Specifically in the lobular histology sub-type of breast cancer, some lobular carcinomas contain a higher number of somatic mutations than other lobular cancers and have a worse prognosis (20). These could represent an opportunity for therapeutic targeting.

The number of mutations in a tumor may predict benefit from CTLA-4 inhibitor treatment. This was the conclusion of a study in melanoma patients treated with ipilimumab that examined mutation load by whole exome sequencing (57). Patients with long-term benefit from the drug had a higher number of exomic missense mutations than patients that did not derived any benefit or had only minimal benefit. In addition, patients with more than 100 mutations in their exomes had a higher overall survival after ipilimumab treatment than patients with a lower number of mutations (57).

Presentation of neo-antigens involves MHC I molecules expression in tumor cell surface. This expression is regulated by $\gamma \delta \mathrm{T}$ cells and natural killer (NK) cells infiltrating the tumor microenvironment and producing interferon $\gamma($ IFN- $\gamma$ ) (58). MCH II expression is also important in immune response regulation in triple-negative breast cancers (59). Tumors with high MHC II expression are able to mount an immune response and have a better progression-free survival than counterparts with low MCH II. This is an important step because unstable cancers may still not respond optimally to immune treatments if they are unable to present neo-antigens to the immune system. Moreover, infiltration by CD4+ helper $\mathrm{T}$ cells may decrease expression of PD-L1 on the surface of breast tumor-specific cytotoxic CD8+ cells, preventing their exhaustion (60). Thus, a variety of cells in the immune infiltrate are necessary for antigen presentation and mounting an antitumor response by the immune system to an immunogenic cancer, which explains the fact that the type of the immune infiltrate is a parameter that has to be taken into consideration, in addition to the total number of TILs, as mentioned in the previous section (61).

\section{Preclinical Studies on Immune Blockade in Breast Cancer}

Molecular pathways and factors that modulate expression of immune blockade molecules in tumor cells are of interest because their knowledge may lead to interventions to manipulate them for clinical benefit. Regulation may result 
from exogenous signals from the tumor microenvironment but also from intra-cellular signals resulting from oncogenesis-related pathways (Figure 1). Molecular lesions affecting the PI3K/Akt pathway are common in breast cancers. Phosphatase and tensin homolog (PTEN) downregulation or loss is one of these lesions and leads to upregulation of PD-L1 expression (22). Breast cancer cells with high activity of the pathway displayed high PD-L1 expression, which was decreased by treatment with an Akt inhibitor or the mammalian target of rapamycin (mTOR) inhibitor rapamycin (kinase mTOR is down-stream of $\mathrm{PI} 3 \mathrm{~K} / \mathrm{Akt}$ ). PI3K/Akt pathway is also downstream of EGFR/Her2 receptors and activation leads to trastuzumab resistance (62). Treatment with combination of a Her2 antibody and the Akt inhibitor triciribine reverses this resistance and inhibits human xenografts overexpressing Her2 in a mouse model. In addition, increased $\mathrm{T}$ cell infiltrates were observed after combination treatment and further enhancement of antineoplastic effect of the combination was obtained by adding an anti-CTLA-4 antibody (62). The RAS/MAPK pathway is also situated downstream of EGFR/Her2 receptors signaling and their activation is associated with reduced TILs in triple-negative breast cancer (63). Inhibition of the pathway with a MEK inhibitor results in up-regulation of both MHC I molecules and PD-L1 in triple-negative cancer cell surface and combination of MEK and PD-L1 inhibition synergize to inhibit the growth of these cells in an in vivo mouse model (63). Up-regulation of PD-L1 through activation of both the RAS/MAPK and the PI3K/Akt pathway is observed additionally in non-small cell lung cancer (NSCLC) mutant for $E G F R$ or carrying the EML4-ALK translocation, suggesting that these oncogenic pathways have a consistent role in PD-L1 expression regulation in several types of cancers where they are activated (64).

The oncogene $M Y C$ is a transcriptional regulator of PDL1 and additionally of receptor CD47 that inhibits innate response in murine and human cancer cells (65). MYC inactivation led to suppression of both immune molecules expression and tumor growth inhibition and increased immune cells infiltration in vivo.

Chemotherapeutic agents, such as paclitaxel, 5fluorouracil (5-FU) and etoposide, used in breast cancer treatment (the first two in both the adjuvant and metastatic setting and the third in the metastatic setting) have been found to up-regulate PD-L1 in the breast cancer cell line MDA-MB-468 (66) (Figure 1). This up-regulation promoted apoptosis of co-cultured $\mathrm{T}$ cells. IFN- $\gamma$ could up-regulate PD-L1 expression in breast cancer cell lines and this upregulation was more pronounced in basal type cell lines that have a higher baseline PD-L1 expression (67).

Tumor suppressor p53 down-regulates PD-L1 expression through induction of miR-34 and miR-200 $(68,69)$. In tumor

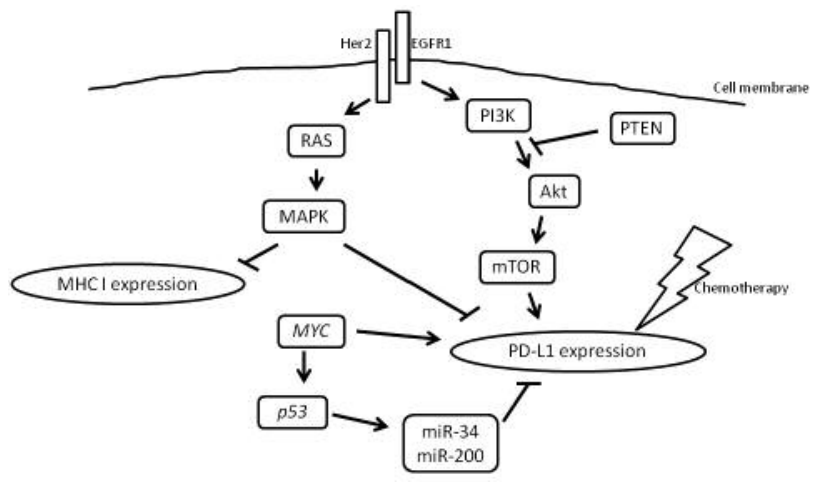

Figure 1. Activation of PD-L1 expression by oncogenic pathways downstream of receptor tyrosine kinases. The EGFR1/ Her2 heterodimer is depicted in the figure as an example. PD-L1 is up-regulated additionally by oncogene MYC and chemotherapeutic drugs. Debilitating mutations of tumor suppressor p53 that would otherwise down-regulate PD-L1 translation through miR-34 and miR-200 family miRs result in PD-L1 up-regulation. The RAS/MAPK pathway downregulates the expression of MHC I molecules in tumor cells decreasing their ability to present neo-antigens to the immune system.

cells with mutated $p 53$, these miRs are down-regulated and, as a result, $P D-L 1$ mRNA is translated, contributing to immune evasion (Figure 1). Both miR-34 and miR-200 families have additional targets. For example miR-200s participate in epithelial mesenchymal transition (EMT), associating invasion and metastasis with immune evasion.

The regulation of immune blockade molecules in cancer cells by carcinogenesis-associated pathways could be used therapeutically in combination treatments, including inhibitors of these pathways and immune blockade inhibitors whence the first drug would contribute to down-regulation of expression of immune blockade molecules making their inhibition by the second drug easier to effect. On the other hand, activation of down-regulated tumor suppressor pathways, such as p53, have been notoriously difficult to accomplish but, theoretically, it could be boosted by combining with immune blockade inhibitors.

\section{Integration of Predictive Factors}

Integration of predictive factors for response to immune blockade inhibitors could be the optimal means of predicting response at the individual patient level and optimizing treatment offered. An interesting model of classifying cancers taking into consideration PD-L1 expression by tumor cells and presence of TILs has been proposed and could be used as a predictive tool of response to PD-L1 inhibitors (70). According to this schema, cancers can be viewed as belonging to one of four categories: Cancers expressing PD-L1 and 
positive for TILs, cancers negative for PD-L1 and TILs, cancers expressing PD-L1 but without TILs and, lastly, cancers negative for PD-L1 expression but infiltrated by TILs (70). Cancers in the first category are believed to have acquired an adaptive immune resistance by expressing PD-L1 in order to neutralize invading TILs. They constitute the most probable candidate group for effective anti-PD-L1 immune blockade treatment. Those cancers in the second group are believed to be ignored by the immune system, for example because they do not present neo-antigens. Cancers in the third group express PD-L1 due to intrinsic activation of expression, for example due to oncogene pathways activity and not due to extrinsic TILs pressure. Both the second and third group could be candidates for combination treatments with anti-CTLA4 inhibitors to induce TILs by improved antigen presentation in remote lymphoid organs, as well as chemotherapy or radiotherapy to induce tumor neo-antigen presentation due to tumor cell death with or without addition of anti-PD-L1 inhibitors. The fourth group, cancers with TILs but without PD-L1 expression on tumor cells are believed to have developed immune tolerance due to alternative immune blockade pairs, such as T-cell immunoglobulin and mucindomain containing-3 (TIM3)/ galectin 9 or $\mathrm{B}$ and $\mathrm{T}$ lymphocyte attenuator/herpes virus entry mediator (BTLA/HVEM), and could benefit for development of inhibitors of these molecules in the future (71). This schematic framework could be further improved by including other parameters, such as genetic instability and types of TILs in order to increase its usefulness. Additional candidates could be circulating lymphocytes or serum proteins associated with immune responses such, as C-reactive protein (CRP) and lactate dehydrogenase ( $\mathrm{LDH})(72,73)$. The model could also be modified to include CTLA4 expression for use in prediction of anti-CTLA4 therapies efficacy. If validated clinically, it could aid in personalized immunotherapy development and, thus, increase efficacy and decrease adverse effects and cost by avoiding treatment in patients predicted not to benefit from a specific treatment. Any predictive model would have to be robust and reproducible to enter the clinic as clinicians are generally reluctant to exclude patients from a treatment even if the probability of benefit is small, especially if there are no many therapeutic alternatives.

\section{Immune Blockade Inhibitors Currently Used and Investigated in Cancer}

The first immune blockade pair that was pharmacologically targeted in cancer was the CD80/CD86 ligand- CTLA-4 receptor present in the presentation synapse, but also in the tumor microenvironment. When an antigen bearing MHC II molecule on an APC binds the TCR on an effector T cell and concomitantly CD80 or CD86 ligands bind CTLA-4 inhibiting co-receptor, instead of the activating CD28 receptor, the $\mathrm{T}$ cell becomes anergic instead of activated. The monoclonal antibody ipilimumab binds CTLA-4 and prevents its interaction with CD80 and CD86 that may then engage the activating CD28. In this way, activation is favored at the expense of anergy and apoptosis of the T cell that bears the blocked CTLA-4. Ipilimumab is currently approved for the treatment of metastatic melanoma and benefit has been demonstrated with adjuvant treatment of node-positive melanoma, which led to the recent approval of ipilimumab for this indication by the American Food and Drug Administration (FDA) $(74,75)$.

More recently, inhibitors of the PD-L1/PD-L2- PD-1 pair have become clinically available. Inhibition of this interaction may activate the immune anti-tumor response in both the presentation and the effector step as PD-L molecules are expressed by both APCs and cancer cells. Two monoclonal antibodies against PD-1, nivolumab and pembrolizumab, are currently in clinical use. Nivolumab is approved alone and in combination with ipilimumab in metastatic melanoma and as monotherapy in metastatic NSCLC and renal cell carcinoma. Pembrolizumab is used in metastatic melanoma. Both drugs have shown impressive activity in phase III trials in these cancers with a very manageable toxicity profile (76-80). Several advanced trials seek to expand these indications to other cancers, among which is breast cancer, and investigate additional immune blockade inhibitors. For example, in an expanded phase I study of metastatic bladder transitional cell carcinoma patients, the monoclonal anti-PD-L1 antibody atezolizumab (also known as MPDL3280A) has shown remarkable activity (81). About $25 \%$ of patients obtained an objective response and another $30 \%$ had stable disease. Response rates were even higher $(42 \%)$ in patients with the highest expression of PD-L1 in their TILs. Atezolizumab has just obtained regulatory approval for the indication of metastatic platinum-refractory transitional carcinoma of the urinary bladder. In another expanded phase I multinational study of the anti-PD-1 antibody pembrolizumab in patients with mostly pretreated advanced gastric cancers, the response rate observed was $22 \%$ (eight of 36 evaluable patients) and an additional five patients had stable disease (82). This cohort was part of a larger study that included also other cancer sites and only patients positive for PD-L1 (defined as at least $1 \%$ positive tumor cells in a single histologic section).

More rare sub-types of common cancers, such as smallcell lung cancer (SCLC) or rare types of cancer, such as Merkel-cell carcinoma have, additionally, been studied and displayed sensitivity to immune blockade inhibitors $(83,84)$.

\section{Clinical Studies of Immune Blockade Inhibitors in Breast Cancer}

Initial results of immune blockade inhibitors clinical studies in breast cancer have been reported. A phase I study examined 
Table III. Candidate treatments for combination with immune blockade inhibitors.

- Chemotherapy (e.g. nab-paclitaxel).

- Radiation therapy (abscopal phenomenon).

- Other immune modulators (CD73 inhibitors, adenosine receptor antagonists).

- Other targeted therapies used in breast cancer (e.g. ado-trastuzumab emtansine in Her2-positive carcinomas).

- Repurposing of drugs used in other indications for combination (e.g. avacimibe).

- Stem cells/stemness inhibitors.

the combination of the aromatase inhibitor exemestane with the anti-CTLA4 monoclonal antibody tremelimumab in patients with pre-treated hormone-sensitive metastatic breast cancer (85). The maximal tolerated dose (MTD) of tremelimumab was determined to be $6 \mathrm{mg} / \mathrm{kg}$ every 90 days in combination with the standard $25 \mathrm{mg}$ oral dose of exemestane daily. Although no objective responses were observed, $42 \%$ of patients had stable disease for at least three months (85). A third of these patients had previously progressed in exemestane monotherapy. Of interest, an increase in the ratio of ICOS+ activated T cells to FOXP3+ regulatory $\mathrm{T}$ cells was observed after tremelimumab treatment.

Pembrolizumab has been evaluated in patients with ERpositive, Her2-negative metastatic breast cancer and in triplenegative patients $(86,87)$. Twenty five heavily pretreated patients were included in the ER-positive, Her2-negative study and $19 \%$ had tumors positive for PD-L1 (86). The overall response rate (ORR) observed was $14 \%$ and responses seemed to be long-lived. Overall tolerance was good and no new concerns regarding auto-immune toxicity have emerged. In the triple-negative phase I $\beta$ study, 111 heavily pre-treated patients with PD-L1-positive (defined as $>1 \%$ expression in tumor or stromal cells) disease were included and received $10 \mathrm{mg} / \mathrm{kg}$ of pembrolizumab every 2 weeks as monotherapy (87). Twenty-seven patients were evaluable for response and had an ORR of $18.5 \%$ with a duration of 15 weeks to more than 47 weeks. Grade 3 or higher toxicity was observed in $15.6 \%$ of patients and there was one treatment-related death from disseminated intravascular coagulation in a patient with rapidly progressive disease not responding to three previous lines of therapy (87).

A study examining the PD-L1 monoclonal antibody avelumab had included 168 pretreated (up to three lines of therapy) patients with locally advanced or metastatic breast cancer with all sub-types (88). About $43 \%$ of patients had hormone receptor-positive, Her2-negative disease, $15.5 \%$ were Her2-positive and $34.5 \%$ were triple-negative. ORR was only $4.8 \%$ but in triple-negative patients it was somewhat higher at $8.6 \%$. Median duration of response in responding patients exceeded 6 months and tolerance was acceptable.

Another PD-L1 monoclonal antibody, atezolizumab, was studied in metastatic triple-negative breast cancer patients (89). Of 53 patients included, 21 had expression of PD-L1 in 5\% or more of their TILs. Five of these 21 patients (24\%) showed a response ( $3 \mathrm{PR}$ and $2 \mathrm{CR}$ ) and an additional three patients (14\%) had a pseudoprogression (a mixed response, occasionally followed by regression). Six of the 54 patients $(11 \%)$ had severe (grade 3 and 4) adverse events (mainly cytopenias).

Several other trials are in progress but results are not available yet. These include studies in the neoadjuvant setting, studies with additional drugs as monotherapies, such as the PD-1 antibody PDR001 (study number NCT02404441, clinicaltrials.gov, accessed July 29, 2016), as well as combinations, some of which will be discussed in the following section.

\section{Perspectives: Combination Treatments to Increase Efficacy}

Immune blockade inhibitors may be a valid treatment for some patients with breast cancer, especially of triple-negative or Her2-positive sub-sets. Nevertheless, based on the available data the majority of patients, even in these sub-sets, do not respond and responses are even rarer in ER-positive sub-sets. Prognostic markers present the opportunity to better define expected responders and possibly could guide improved therapeutic plans with combinations of immune blockade inhibitors with other drugs and therapeutic modalities, if coupled with a better understanding of the cause of resistance (Table III).

A combination treatment that could produce superior responses compared to monotherapy based on the melanoma experience is with immune blockade inhibitors targeting different molecules. In patients with metastatic melanoma having received no previous therapy, the combination of ipilimumab and nivolumab was more effective than monotherapy with ipilimumab (90). Response rate in the combination arm was $61 \%$ (22\% complete responses) and in the ipilimumab arm only $11 \%$ (all partial responses). Progression-free survival also significantly increased with the combination. This study included mostly $B R A F$ wild-type patients, but the small number of BRAF V600E mutant patients included had a similar benefit (90). Adverse effects were more common in the combination arm and were the most common reason of discontinuation of treatment in this arm, as opposed to the monotherapy arm where disease 
progression was the most common discontinuation cause. Based on these encouraging results, combinations with checkpoint inhibitors could be a strategy to pursue in other types of cancers, including breast cancer, to increase response rates and induce responses in patients unresponsive to monotherapies. The effectiveness of this combination strategy may rely on the fact that inhibition of PD-1 engagement in immune cells, besides activating these cells, induces activation of CTLA4 receptors in cell surface, thus leading to feedback inhibition (91).

Another inhibitory immune receptor that is induced after PD-1 inhibition resulting in $\mathrm{T}$ cell activation is the adenosine receptor $2 \mathrm{~A}(92)$. This receptor is activated by ligation to its ligand adenosine, produced from hydrolysis of AMP catalyzed by ectonucleotidase CD73. Activation of the adenosine receptor $2 \mathrm{~A}$ in the membrane of $\mathrm{T}$ cells leads to a feedback inhibition of $\mathrm{T}$ cell activation. Inhibition of CD73 by the use of a monoclonal antibody enhanced the activity of anti-PD-1 and anti-CTLA-4 antibodies in mouse models of colon, prostate and breast cancer xenografts (93). Alternatively, adenosine receptor $2 \mathrm{~A}$ may be inhibited directly by receptor antagonists. One such drug, tozadenant, is in clinical trials for Parkinson's disease and has been proved to be safe (94). Thus, it could be more easily repurposed for combination immunotherapy treatment in cancer. In addition of being a potential therapeutic target, expression of CD73 in triple-negative breast cancers is a predictive marker of anthracycline resistance (95). It has also been proposed as a marker of response to anti-PD-1 treatments (96). Thus, CD73 deserves to be further studied as a predictive marker of multiple other treatments in addition to being a putative predictive bio-marker of its own pathway inhibition.

Her2-positive breast cancer patients receive anti-Her2 monoclonal antibodies as part of their treatment that work by direct cytotoxicity to tumor cells but also by eliciting antibody dependent immune responses. A preclinical in vivo study in mice has shown that the monoclonal anti-Her2 antibody- drug conjugate ado-trastuzumab emtansine (TDM1) in combination with anti-CTLA4 or anti-PD-1 antibodies led to responses in xenografted tumors that had been resistant to T-DM1 monotherapy (97). The combination of trastuzumab with pembrolizumab is now investigated in a phase Ib-II trial (PANACEA trial, NCT02129556) in patients with metastatic Her-2 positive breast cancers resistant to trastuzumab (clinicaltrials.gov, accessed July 2, 2016).

Another combination that has produced encouraging preclinical results in a melanoma mouse model used the combination of an anti-PD-1 antibody and the cholesterol lowering drug avasimibe, an ACAT1 (Acyl-coenzyme A: cholesterol acyltransferase 1) inhibitor (98). Avasimibe boosts CD8+ lymphocytes cytotoxicity by increasing cholesterol content in their membrane, which enhances $\mathrm{T}$ cell receptor clustering and immune synapses formation. The combination of avasimibe with an anti-PD-1 antibody led to improved tumor control and survival of melanoma-bearing mice than either drugs alone (98).

Chemotherapy drugs are currently the backbone of therapy for triple-negative metastatic breast cancers. As previously discussed, these drugs up-regulate immune blockade molecules and, thus, immune blockade inhibitors combined with chemotherapeutics could reverse resistance derived from this up-regulation. A phase III trial comparing the combination of a protein-bound form of paclitaxel (nabpaclitaxel) and atezolizumab with nab-paclitaxel monotherapy in patients with metastatic triple-negative breast cancer is on-going (99).

Radiation therapy has systemic effects derived from immune stimulation and its combination with immune blockade inhibitors to boost these effects is under investigation $(100,101)$. Systemic effects of radiation, referred to as abscopal, are derived from destruction of tumor cells that elicit antigen production, as well as other effects, such as production of cytokines, that stimulate the immune system and up-regulation of MHC I molecules and danger signals (102). Concomitantly, checkpoint molecule PD-L1 is also up-regulated in irradiated tissues. Thus, the combination of inhibitors blocking PD-L1, PD-1 or CTLA4 has the potential to act synergistically with radiation (103).

Significant enthusiasm and resources have been dedicated over the past decades to the field of cancer vaccines with frustratingly disappointing results overall (104). Various techniques and antigens have been used over the years with concomitant adjuvants to induce clones of cytotoxic lymphocytes with tumor antigen specificity. This production has been used as evidence of "success" for the strategy but clinical responses had been rare. More recently with the understanding that immune blockade molecules may be one of the major hurdles of in vivo activity for the produced antitumor clones, a combination of vaccination with checkpoint inhibitors has been studied in early trials in melanoma (105). Although still early, so far, the addition of vaccines has not increased the effectiveness of ipilimumab, suggesting that optimization of the techniques and timing is needed.

As discussed in a previous section, resistance to PDL1/PD-1 inhibition may be associated with up-regulation of alternative immune blockade pairs. An in vivo pre-clinical study in mice bearing non-small cell carcinoma xenografts has shown that resistant tumors developed in mice treated with anti-PD-1 antibodies and were associated with higher expression of TIM-3 in T cells (106). Treatment with antiTIM-3 antibodies concomitantly to anti-PD-1 antibodies prevented development of resistance and, thus, could be a candidate therapy to be further pursued. Activating antibodies of immune co-activators, such as OX40, could be an alternative strategy for combination development (107). Another immune co-activator, ICOS, though, promotes 
interaction of Tregs with plasmacytoid dentritic cells in breast tumor microenvironment, leading to immune escape (108). Thus, not all co-activator pair stimulation would necessarily result in anti-tumors immune response promotion and effects of specific interventions need to be carefully studied in preclinical models before advancing to clinical trials.

Resistance to therapies in cancer in general and breast cancer in particular may be mediated by cancer stem cells (CSCs), a sub-set of cancer cell populations with the ability to repopulate tumors and produce the cell heterogeneity of cancers (109). Cells with the breast cancer stem cell phenotype arise after treatment of Her2-positive tumors with trastuzumab and polyclonal NK cells mediating antibodydependent cell-mediated cytotoxicity (ADCC) (110). These cells that arise after treatment have undergone an EMT that is associated with expression of pluripotency phenotypes (111). A similar phenomenon with expression of pluripotency proteins, such as Nanog, has been observed following development of resistance to antitumor vaccines (112). Decreased expression of immune response molecules, such as MCH I and II and NK cells activating ligands by CSCs may mediate their lower immunogenicity as suggested for CSCs in the case of glioblastoma (113). Immune checkpoint proteins in breast CSCs could also mediate their decreased immunogenicity as suggested by these studies and could be reversed by immune blockade inhibitors, providing an additional rational for combinations with existing monoclonal antibody therapies in breast cancer.

As evidenced from this discussion, not all of the combinations proposed have been studied in breast cancer models but, based on the experience with immune blockade inhibitors so far, their effectiveness is more dependent on the immunogenicity of the cancers and the role played by the molecule to be inhibited in the particular tumor microenvironment. These considerations would argue for a high probability of success of these combinations in breast cancer under the right conditions. These "right conditions" are the biomarkers needed to be developed in parallel (companion diagnostics) with the immune blockade inhibitor drugs in clinical trials for harnessing their maximal benefit in breast cancer patients (114). With these predictive biomarkers as tools it may become possible to target not only the more immunogenic triple-negative and Her2-positive cancers but also sub-sets of ER-positive ones.

\section{References}

1 Goss PE, Ingle JN, Martino S, Robert NJ, Muss HB, Piccart MJ Castiglione M, Tu D, Shepherd LE, Pritchard KI, Livingston RB, Davidson NE, Norton L, Perez EA, Abrams JS, Therasse P, Palmer MJ and Pater JL: A randomized trial of letrozole in postmenopausal women after five years of tamoxifen therapy for early-stage breast cancer. N Engl J Med 349: 1793-1802, 2003.
2 Slamon DJ, Leyland-Jones B, Shak S, Fuchs H, Paton V, Bajamonde A, Fleming T, Eiermann W, Wolter J, Pegram M, Baselga $\mathrm{J}$ and Norton L: Use of chemotherapy plus a monoclonal antibody against HER 2 for metastatic breast cancer that overexpresses HER2. N Engl J Med 344: 783-792, 2001.

3 Romond EH, Perez EA, Bryant J, Suman VJ, Geyer CE, Davidson NE, Tan-Chiu E, Martino S, Paik S, Kaufman PA, Swain SM, Pisansky TM, Fehrenbacher L, Kutteh LA, Vogel VG, Visscher DW, Yothers G, Jenkins RB, Brown AM, Dakhil SR, Mamounas EP, Lingle WL, Klein PM, Ingle JN and Wolmark N: Trastuzumab plus adjuvant chemotherapy for operable HER2positive breast cancer. N Engl J Med 353: 1673-1684, 2005.

4 Goss PE, Ingle JN, Pritchard KI, Robert NJ, Muss H, Gralow J, Gelmon K, Whelan T, Strasser-Weippl K, Rubin S, Sturtz K, Wolff AC, Winer E, Hudis C, Stopeck A, Beck JT, Kaur JS, Whelan $\mathrm{K}, \mathrm{Tu} \mathrm{D}$ and Parulekar WR: Extending aromataseinhibitor adjuvant therapy to 10 years. N Engl J Med 375: 209219, 2016.

5 Verma S, Miles D, Gianni L, Krop IE, Welslau M, Baselga J, Pegram M, Oh DY, Diéras V, Guardino E, Fang L, Lu MW, Olsen S, Blackwell K and EMILIA Study Group: Trastuzumab emtansine for HER2-positive advanced breast cancer. N Eng1 J Med 368: 1783-1791, 2013.

6 Burstein MD, Tsimelzon A, Poage GM, Covington KR, Contreras A, Fuqua SAW, Savage MI, Osborne CK, Hilsenbeck SG, Chang JC, Mills GB, Lau CC and Brown PH: Comprehensive genomic analysis identifies novel subtypes and targets of triple-negative breast cancer. Clin Cancer Res 21: 1688-1698, 2015.

7 Lehmann BD, Bauer JA, Chen X, Sanders ME, Chakravarthy AB, Shyr Y and Pietenpol JA: Identification of human triple-negative breast cancer subtypes and preclinical models for selection of targeted therapies. J Clin Invest 121: 2750-2767, 2011.

8 Tutt A, Robson M, Garber JE, Domchek SM, Audeh MW, Weitzel JN, Friedlander M, Arun B, Loman N, Schmutzler RK, Wardley A, Mitchell G, Earl H, Wickens M and Carmichael J: Oral poly(ADP-ribose) polymerase inhibitor olaparib in patients with BRCA1 or BRCA2 mutations and advanced breast cancer: a proof-of-concept trial. Lancet 376: 235-244, 2010.

9 Dustin ML: The immunological synapse. Cancer Immunol Res 2: 1023-1033, 2014.

10 Sigal LH: Basic science for the clinician 55: CTLA-4. J Clin Rheumatol 18: 155-158, 2012.

11 Ward FJ, Dahal LN, Wijesekera SK, Abdul-Jawad SK, Kaewarpai T, Xu H, Vickers MA and Barker RN: The soluble isoform of CTLA-4 as a regulator of T-cell responses. Eur $\mathrm{J}$ Immunol 43: 1274-1285, 2013.

12 Khalil DN, Smith EL, Brentjens RJ and Wolchok JD: The future of cancer treatment: immunomodulation, CARs and combination immunotherapy. Nat Rev Clin Oncol xx: 1-18, 2016.

13 Yu H, Yang J, Jiao S, Li Y, Zhang W and Wang J: Cytotoxic T lymphocyte antigen 4 expression in human breast cancer: implications for prognosis. Cancer Immunol Immunother 64: 853-860, 2015.

14 Contardi E, Palmisano GL, Tazzari PL, Martelli AM, Falà F, Fabbi M, Kato T, Lucarelli E, Donati D, Polito L, Bolognesi A, Ricci F, Salvi S, Gargaglione V, Mantero S, Alberghini M, Battista Ferrara G and Pia Pistillo M: CTLA-4 is constitutively expressed on tumor cells and can trigger apoptosis upon ligand interaction. Int J Cancer 117: 538-550, 2005. 
15 Jaberipour M, Habibagahi M, Hosseini A, Rezai Habibabad S, Talei A and Ghaderi A: Increased CTLA-4 and FOXP3 transcripts in peripheral blood mononuclear cells of patients with breast cancer. Pathol Oncol Res 16: 547-551, 2010.

16 Erfani N, Razmkhah $\mathrm{M}$ and Ghaderi A: Circulating soluble CTLA4 (sCTLA4) is elevated in patients with breast cancer. Cancer Invest 28: 828-832, 2010.

17 Schalper KA, Velcheti V, Carvajal D, Wimberly H, Brown J, Pusztai L and Rimm DL: In situ tumor PD-L1 mRNA expression is associated with increased TILs and better outcome in breast carcinomas. Clin Cancer Res 20: 2773-2782, 2014.

18 Sabatier R, Finetti P, Mamessier E, Adelaide J, Chaffanet M, Raza Ali H, Viens P, Caldas C, Birnbaum D and Bertucci F: Prognostic and predictive value of PDL1 expression in breast cancer. Oncotarget 6: 5449-5464, 2014.

19 Barrett MT, Anderson KS, Lenkiewicz E, Andreozzi M, Cunliffe HE, Klassen CL, Dueck AC, McCullough AE, Reddy SK, Ramanathan RK, Northfelt DW and Pockaj BA: Genomic amplification of 9p24.1 targeting JAK2, PD-L1, and PD-L2 is enriched in high-risk triple-negative breast cancer. Oncotarget 6: 26483-26493, 2015.

20 Michaut M, Chin S-F, Majewski I, Severson TM, Bismeijer T, de Koning L, Peeters JK, Schouten PC, Rueda OM, Bosma AJ, Tarrant F, Fan Y, He B, Xue Z, Mittempergher L, Kluin RJC, Heijmans J, Snel M, Pereira B, Schlicker A, Provenzano E, Raza Ali H, Gaber A, O'Hurley G, Lehn S, Muris JJF, Wesseling J, Kay E, Sammut SJ, Bardwell HA, Barbet AS, Bard F, Lecerf C, O'Connor DP, Vis DJ, Benes CH, McDermott U, Garnett MJ, Simon IM, Jirström K, Dubois T, Linn SC, Gallagher WM, Wessels LFA, Caldas C and Bernards R: Integration of genomic, transcriptomic and proteomic data identifies two biologically distinct subtypes of invasive lobular breast cancer. Sci Rep 6: 18517, 2016.

21 Ali HR, Glont S-E, Blows FM, Provenzano E, Dawson S-J, Liu B, Hiller L, Dunn J, Poole CJ, Bowden S, Earl HM, Pharoah PDP and Caldas C: PD-L1 protein expression in breast cancer is rare, enriched in basal-like tumours and associated with infiltrating lymphocytes. Ann Oncol 26: 1488-1493, 2015.

22 Mittendorf EA, Philips AV,Meric-Bernstam F, Qiao N, Wu Y, Harrington S, Su X, Wang Y, Gonzalez-Angulo AM, Akcakanat A, Chawla A, Curran M, Hwu P, Sharma P, Litton JK, Molldrem JJ and Alatrash G: PD-L1 expression in triplenegative breast cancer. Cancer Immunol Res 2: 361-370, 2014.

23 Ghebeh H, Mohammed S, Al-Omair A, Qattan A, Lehe C, AlQudaihi G, Elkum N, Alshabanah M, Bin Amer S, Tulbah A, Ajarim D, Al-Tweigeri T and Dermime S: The B7-H1 (PD-L1) $\mathrm{T}$ lymphocyte-inhibitory molecule is expressed in breast cancer patients with infiltrating ductal carcinoma: Correlation with important high-risk prognostic factors. Neoplasia 8: 190-198, 2006.

24 Muenst S, Schaerli AR, Gao F, Däster S, Trella E, Droeser RA, Muraro MG, Zajac P, Zanetti R, Gillanders WE, Weber WP and Soysal SD: Expression of programmed death ligand 1 (PD-L1) is associated with poor prognosis in human breast cancer. Breast Cancer Res Treat 146: 15-24, 2014.

25 Qin T, Zeng Y, Qin G, Xu F, Lu J, Fang W, Xue C, Zhan J, Zhang X, Zheng Q, Peng R, Yuan Z, Zhang L and Wang S: High PD-L1 expression was associated with poor prognosis in 870 Chinese patients with breast cancer. Oncotarget 6: 33972$33981,2015$.
26 Baptista MZ, Sarian LO, Derchain SFM, Pinto GA and Vassallo $\mathrm{J}$ : Prognostic significance of PD-L1 and PD-L2 in breast cancer. Hum Pathol 47: 78-84, 2016.

27 Mazel M, Jacot W, Pantel K, Bartkowiak K, Topart D, Cayrefourcq L, Rossille D, Maudelonde T, Fest T and AlixPanabières C: Frequent expression of PD-L1 on circulating breast cancer cells. Mol Oncol 9: 1773-1782, 2015.

28 Kawaguchi K, Suzuki E, Yamaguchi A, Yamamoto M, Morita $\mathrm{S}$ and Toi M: Altered expression of major immune regulatory molecules in peripheral blood immune cells associated with breast cancer. Breast Cancer [Epub ahead of print], 2016.

29 Muenst S, Soysal SD, Gao F, Obermann EC, Oertli D and Gillanders WE: The presence of programmed death 1 (PD-1)positive tumor-infiltrating lymphocytes is associated with poor prognosis in human breast cancer. Breast Cancer Res Treat 139: 667-676, 2013.

30 Loi S, Drubay D, Adams S, Francis PAA, Joensuu H, Dieci MV, Badve S, Demaria S, Gray R, Piccart MJJ, KellokumpaLehtinen P-L, Andre F, Dufaure-Gare I, Denkert C, Salgado R and Michiels S: Pooled individual patient data analysis of stromal tumor infiltrating lymphocytes in primary triplenegative breast cancer treated with anthracycline-based chemotherapy. San Antonio Breast Cancer Symposium S1-03, 2015.

31 Ibrahim EM, Al-Foheidi ME, Al-Mansour MM and Kazkaz GA: The prognostic value of tumor-infiltrating lymphocytes in triple-negative breast cancer: a meta-analysis. Breast Cancer Res Treat 148: 467-476, 2014

32 Loi S, Michiels S, Salgado R, Sirtaine N, Jose V, Fumagalli D, Kellokumpu-Lehtinen P-L, Bono P, Kataja V, Desmedt C, Piccart MJ, Loibl S, Denkert C, Smyth MJ, Joensuu H and Sotiriou C: Tumor infiltrating lymphocytes are prognostic in triple-negative breast cancer and predictive for trastuzumab benefit in early breast cancer: results from the FinHER trial. Ann Oncol 25: 1544-1550, 2014.

33 Hida AI, Sagara Y, Yotsumoto D, Kanemitsu S, Kawano J, Baba S, Rai Y, Oshiro Y, Aogi K, Sagara S and Ohi Y: Prognostic and predictive impacts of tumor infiltrating lymphocytes differ between triple-negative and HER2-positive breast cancers treated with standard systemic therapies. Breast Cancer Res Treat 158: 1-9, 2016.

34 Mao Y, Qu Q, Zhang Y, Liu J, Chen X and Shen K: The value of Tumor Infiltrating Lymphocytes (TILs) for predicting response to neoadjuvant chemotherapy in breast cancer: A systematic review and meta-analysis. PLoS one 9: e115103, 2014.

35 Bianchini G, Pusztai L, Pienkowski T, Im Y-H, Bianchi GV, Tseng L-M, Liu M-C, Lluch A, Galeota E, Magazzù D, de la Haba-Rodríguez J, Oh D-Y, Poirier B, Pedrini JL, Semiglazov $\mathrm{V}$, Valagussa $\mathrm{P}$ and Gianni L: Immune modulation of pathologic complete response after neoadjuvant HER2-directed therapies in the NeoSphere trial. Ann Oncol 26: 2429-2436, 2015.

36 Issa-Nummer Y, Darb-Esfahani S, Loibl S, Kunz G, Nekljudova V, Schrader I, Valentin Sinn B, Ulmer H-U, Kronenwett R, Just M, Kühn T, Diebold K, Untch M, Holms F, Blohmer J-U, Habeck J-O, Dietel M, Overkamp F, Krabisch P, von Minckwitz G and Denkert C: Prospective validation of immunological infiltrate for prediction of response to neoadjuvant chemotherapy in HER2-negative breast cancer- A substudy of the neoadjuvant GeparQuinto trial. PLoS ONE 8: e79775, 2013. 
37 Nabholtz JM, Abrial C, Mouret-Reynier MA, Dauplat MM, Weber B, Gligorov J, Forest AM, Tredan O, Vanlemmens L, Petit T, Guiu S, Van Praagh I, Jouannaud C, Dubray-Longeras P, Tubiana-Mathieu N, Benmammar KE, Kullab S, Bahadoor MRK, Radosevic-Robin N, Kwiatkowski F, Desrichard A, Cayre A, Uhrhammer N, Chalabi N, Chollet P and PenaultLlorca F: Multicenter neoadjuvant phase II study of panitumumab combined with an anthracycline/ taxane-based chemotherapy in operable triple-negative breast cancer: identification of biologically defined signatures predicting treatment impact. Ann Oncol 25: 1570-1577, 2014.

38 Wimberly H, Brown JR, Schalper K, Haack H, Silver MR, Nixon C, Bossuyt V, Pusztai L, Lannin DR and Pimm DL: PDL1 expression correlates with Tumor-Infiltrating Lymphocytes and response to neoadjuvant chemotherapy in breast cancer. Cancer Immunol Res 3: 326-332, 2015.

39 Kim ST, Jeong H, Woo OH, Seo JH, Kim A, Lee ES, Shin SW, Kim YH, Kim JS and Park KH: Tumor-infiltrating lymphocytes, tumor characteristics, and recurrence in patients with early breast cancer. Am J Clin Oncol 36: 224-231, 2013.

40 Mahmoud SMA, Paish EC, Powe DG, Macmillan RD, Lee AHS, Ellis IO and Green AR: An evaluation of the clinical significance of FOXP+ infiltrating cells in human breast cancer. Breast Cancer Res Treat 127: 99-108, 2011.

41 Rech AJ, Mick R, Kaplan DE, Chang K-M, Domchek SM and Vonderheide RH: Homeostasis of peripheral FoxP3+ CD4+ regulatory $\mathrm{T}$ cells in patients with early and late stage breast cancer. Cancer Immunol Immunother 59: 599-607, 2010.

42 Verma C, Eremin JM, Robins A, Bennett AJ, Cowley GP, ElSheemy MA, Jibril JA and Eremin O: Abnormal T regulatory cells (Tregs: FOXP3+, CTLA-4+), myeloid-derived suppressor cells (MDSCs: monocytic, granulocytic) and polarized T helper cell profiles (Th1, Th2, Th17) in women with large and locally advanced breast cancers undergoing neoadjuvant chemotherapy (NAC) and surgery: failure of abolition of abnormal treg profile with treatment and correlation of treg levels with pathological response to NAC. J Transl Med 11: 16, 2013.

43 Mahmoud SMA, Lee AHS, Paish EC, Macmillan RD, Ellis IO and Green AR: The prognostic significance of B lymphocytes in invasive carcinoma of the breast. Breast Cancer Res Treat 132: 545-553, 2012

44 Mahmoud SMA, Claire Paish E, Powe DG, Macmillan RD, Grainge MJ, Lee AHS, Ellis IO and Green AR: TumorInfiltrating CD8+ Lymphocytes predict clinical outcome in breast cancer. J Clin Oncol 29: 1949-1955, 2011.

45 Savas P, Salgado R, Denkert C, Sotiriou C, Darcy PK, Smyth $\mathrm{MJ}$ and Loi S: Clinical relevance of host immunity in breast cancer: from TILs to the clinic. Nat Rev Clin Oncol 13: 228$241,2016$.

46 Gubin MM, Zhang X, Schuster H, Caron E, Ward JP, Noguchi T, Ivanova Y, Hundal J, Arthur CD, Krebber W-J, Mulder GE, Toebes M, Vesely MD, Lam SSK, Korman AJ, Allison JP, Freeman GJ, Sharpe AH, Pearce EL, Schumacher TN, Aebersold R, Rammensee H-G, Melief CJM, Mardis ER, Gillanders WE, Artyomov MN and Schreiber RD: Checkpoint blockade cancer immunotherapy targets tumour-specific mutant antigens. Nature 515: 577-581, 2014.

47 Yadav M, Jhunjhunwala S, Phung QT, Lupardus P, Tanguay J, Bumbaca S, Franci C, Cheung TK, Fritsche J, Weinschenk T, Modrusan Z, Mellman I, Lill JR and Delamarre L: Predicting immunogenic tumour mutations by combining mass spectrometry and exome sequencing. Nature 515: 572-576, 2014.

48 Xiao Y and Freeman GJ: The Microsatellite Instable (MSI) subset of colorectal cancer is a particularly good candidate for checkpoint blockade immunotherapy. Cancer Discov 5: 16-18, 2015.

49 Smyrk TC, Watson P, Kaul K and Lynch HT: Tumor-infiltrating lymphocytes are a marker for microsatellite instability in colorectal carcinoma. Cancer 91: 2417-2422, 2001.

50 Llosa NJ, Cruise M, Tam A, Wicks EC, Hechenbleikner EM, Taube JM, Blosser RL, Fan H, Wang H, Luber BS, Zhang M, Papadopoulos N, Kinzler KW, Vogelstein B, Sears CL, Anders RA, Pardoll DM and Housseau F: The vigorous immune microenvironment of microsatellite instable colon cancer is balanced by multiple counter-inhibitory checkpoints. Cancer Discov 5: 43-51, 2015.

51 Le DT, Uram JN, Wang H, Bartlett BR, Kemberling H, Eyring AD, Skora AD, Luber BS, Azad NS, Laheru D, Biedrzycki B, Donehower RC, Zaheer A, Fisher GA, Crocenzi TS, Lee JJ, Duffy SM, Goldberg RM, de la Chapelle A, Koshiji M, Bhaijee F, Huebner T, Hruban RH, Wood LD, Cuka N, Pardoll DM, Papadopoulos N, Kinzler KW, Zhou S, Cornish TC, Taube JM, Anders RA, Eshleman JR, Vogelstein B and Diaz Jr LA: PD-1 blockade in tumors with mismatch-repair deficiency. N Engl J Med 372: 2509-2520, 2015.

52 Dudley JC, Lin MT, Le DT and Eshleman JR: Microsatellite instability as a biomarker for PD-1 blockade. Clin Cancer Res 22: 813-820, 2016

53 Adem C, Soderberg CL, Cunningham JM, Reynolds C, Sebo TJ, Thibodeau SN, Hartmann LC and Jenkins RB: Microsatellite instability in hereditary and sporadic breast cancers. Int J Cancer 107: 580-582, 2003.

54 Lawrence MS, Stojanov P, Polak P, Kryukov GV, Cibulskis K, Sivachenko A, Carter SL, Stewart C, Mermel CH, Roberts SA, Kiezun A, Hammerman PS, McKenna A, Drier Y, Zou L, Ramos AH, Pugh TJ, Stransky N, Helman E, Kim J, Sougnez C, Ambrogio L, Nickerson E, Shefler E, Cortés ML, Auclair D, Saksena G, Voet D, Noble M, DiCara D, Lin P, Lichtenstein L, Heiman DI, Fennell T, Imielinski M, Hernandez B, Hodis E, Baca S, Dulak AM, Lohr J, Landau D-A, Wu CJ, Melendez-Zajgla J, Hidalgo-Miranda A, Koren A, McCarroll SA, Mora J, Lee RS, Crompton B, Onofrio R, Parkin M, Winckler W, Ardlie K, Gabriel SB, Roberts CWM, Biegel JA, Stegmaier K, Bass AJ, Garraway LA, Meyerson M, Golub TR, Gordenin DA, Sunyaev S, Lander ES and Getz G: Mutational heterogeneity in cancer and the search for new cancer-associated genes. Nature 499: 214-218, 2013.

55 Kandoth C, McLellan MD, Vandin F, Ye K, Niu B, Lu C, Xie M, Zhang Q, McMichael JF, Wyczalkowski MA, Leiserson MDM, Miller CA, Welch JS, Walter MJ, Wendl MC, Ley TJ, Wilson RK, Raphael BJ and Ding L: Mutational landscap and significance across 12 major cancer types. Nature 502: 333-339, 2013.

56 Segal NH, Parsons DW, Peggs KS, Velculescu V, Kinzler KW, Vogelstein B and Allison JP: Epitope landscape in breast and colorectal cancer. Cancer Res 68: 889-892, 2008.

57 Snyder A, Makarov V, Merghoub T, Yuan J, Zaretsky JM, Desrichard A, Walsh LA, Postow MA, Wong P, Ho TS, Hollmann TJ, Bruggerman C, Kannan K, Li Y, Elipenahli C, Liu C, Harbison CT, Wang L, Ribas A, Wolchok JD and Chan TA: Genetic basis for clinical response to CTLA-4 blockade in melanoma. N Engl J Med 371: 2189-2199, 2014. 
58 Riond J, Rodriguez S, Nicolau M-L, al Saati T and Gairin E: In vivo major histocompatibility complex class I (MHCI) expression on $\mathrm{MHCI}^{\text {low }}$ tumor cells is regulated by $\gamma \delta \mathrm{T}$ and NK cells during the early steps of tumor growth. Cancer Immunity 9: 10, 2009.

59 Forero A, Li Y, Chen D, Grizzle WE, Updike KL, Merz ND, Downs-Kelly E, Burwell TC, Vaklavas C, Buchsbaum DJ, Myers RM, LoBuglio AF and Varley KE: Expression of the MHC class II pathway in triple-negative breast cancer tumor cells is associated with a good prognosis and infiltrating lymphocytes. Cancer Immunol Res 4: 390-399, 2016.

60 Kmieciak M, Worschech A, Nikizad H, Gowda M, Habibi M, Depcrynski A, Wang E, Godder K, Holt SE, Marincola FM and Manjili MH: CD+ T cells inhibit the neu-specific CD8+ T-cell exhaustion during the priming phase of immune responses against breast cancer. Breast Cancer Res Treat 126: 385-394, 2011.

61 Erdag G, Schaefer JT, Smolkin ME, Deacon DH, Shea SM, Dengel LT, Patterson JW and Slingluff Jr CL: Immunotype and immunohistologic characteristics of tumor-infiltrating immune cells are associated with clinical outcome in metastatic melanoma. Cancer Res 72: 1070-1080, 2012.

62 Wang Q, Li S-H, Wang H, Xiao Y, Sahin O, Brady SW, Li P, Ge H, Jaffee EM, Muller WJ, Hortobagyi GN and Yu D: Concomitant targeting of tumor cells and induction of T-cell response synergizes to effectively inhibit trastuzumab-resistant breast cancer. Cancer Res 72: 4417-4428, 2012.

63 Loi S, Dushyanthen S, Beavis PA, Salgado R, Denkert C, Savas P, Combs S, Rimm DL, Giltnane JM, Estrada MV, Sánchez V, Sanders ME, Cook RS, Pilkinton MA, Mallal SA, Wang K, Miller VA, Stephens PJ, Yelensky R, Doimi FD, Gómez H, Ryzhov SV, Darcy PK, Arteaga CL and Balko JM: RAS/MAPK activation is associated with reduced tumor-infiltrating lymphocytes in triple-negative breast cancer: Therapeutic cooperation between MEK and PD-1/PD-L1 immune checkpoint inhibitors. Clin Cancer Res 22: 1499-1509, 2015.

64 Ota K, Azuma K, Kawahara A, Hattori S, Iwama E, Tanizaki J, Harada T, Matsumoto K, Takayama K, Takamori S, Kage M, Hoshino T, Nakanishi Y and Okamoto I: Induction of PD-L1 expression by the EML4-ALK oncoprotein and downstream signaling pathways in non-small cell lung cancer. Clin Cancer Res 21: 4014-4021, 2015.

65 Casey SC, Tong L, Li Y, Do R, Walz S, Fitzgerald KN, Gouw AM, Baylot V, Gütgemann I, Eilers M and Felsher DW: MYC regulates the antitumor immune response through CD47 and PD-L1. Science 352: 227-231, 2016.

66 Zhang P, Su D-M, Liang M and Fu J: Chemopreventive agents induce programmed death-1-ligand (PD-L1) surface expression in breast cancer cells and promote PD-L1 mediated $\mathrm{T}$ cell apoptosis. Mol Immunol 45: 1470-1476, 2008.

67 Soliman H, Khalil F and Antonia S: PD-L1 expression is increased in a subset of basal type breast cancer cells. PLoS ONE 9: e88557, 2014.

68 Cortez MA, Ivan C, Valdecanas D, Wang X, Peltier HJ, Ye Y, Araujo L, Carbone DP, Shilo K, Giri DK, Kelnar K, Martin D, Komaki R, Gomez DR, Krishnan S, Calin GA, Bader AG and Welsh JW: PDL1 regulation by p53 via miR-34. J Natl Cancer Inst 108: djv303, 2016.

69 Chen L, Gibbons DL, Goswami S, Cortez MA, Ahn Y-H, Byers LA, Zhang X, Yi X, Dwyer D, Lin W, Diao L, Wang J, Roybal
JD, Patel M, Ungewiss C, Peng D, Antonia S, Mediavilla-Varela M, Robertson G, Jones S, Suraokar M, Welsh JW, Erez B, Wistuba II, Chen L, Peng D, Wang S, Ullrich SE, Heymach JV, Kurie JM and Qin FX-F: Metastasis is regulated via microRNA200/ZEB1 axis control of tumour cell PD-L1 expression and intratumoral immunosuppression. Nat Commun 5: 5241, 2014.

70 Teng MWL, Foong Ngiow S, Ribas A and Smyth MJ: Classifying cancers based on T-cell infiltration and PD-L1. Cancer Res 75: 2139-2145, 2015.

71 Pico de Coaña Y, Choudhury A and Kiessling R: Checkpoint blockade for cancer therapy: revitalizing a suppressed immune system. Trends Mol Med 21: 482-491, 2015.

72 Simeone E, Genticore G, Giannarelli D, Grimaldi AM, Caracò C, Curvietto M, Esposito A, Paone M, Palla M, Cavalcanti E, Sandomenico F, Petrillo A, Botti G, Fulciniti F, Palmieri G, Queirolo P, Marchetti P, Ferraresi V, Rinaldi G, Pistillo MP, Ciliberto G, Mozzillo N and Ascierto PA: Immunological and biological changes during ipilimumab treatment and their potential correlation with clinical response and survival in patients with advanced melanoma. Cancer Immunol Immunother 63: 675-683, 2014.

73 Kelderman S, Heemskerk B, van Tinteren H, van den Brom RR, Hospers GA, van den Eertwegh AJ, Kapiteijn EW, de Groot JW, Soetekouw P, Jansen RL, Fiets E, Furness AJ, Renn A, Krzystanek M, Szallasi Z, Lorigan P, Gore ME, Schumacher TN, Haanen JB, Larkin JM and Blank CU: Lactate dehydrogenase as a selection criterion for ipilimumab treatment in metastatic melanoma. Cancer Immunol Immunother 63: 449$458,2014$.

74 van Akkooi ACJ, Atkins MB, Agarwala SS and Lorigan P: Surgical management and adjuvant therapy for high-risk and metastatic melanoma. Am Soc Clin Oncol Ed Book 35: e505e514, 2016.

75 Eggermont AM, Chiarion-Sileni V, Grob JJ, Dummer R, Wolchok JD, Schmidt H, Hamid O, Robert C, Ascierto PA, Richards JM, Lebbé C, Ferraresi V, Smylie M, Weber JS, Maio M, Konto C, Hoos A, de Pril V, Gurunath RK, de Schaetzen G, Suciu S and Testori A: Adjuvant ipilimumab versus placebo after complete resection of high-risk stage III melanoma (EORTC 18071): a randomized, double-blind, phase 3 trial. Lancet Oncol 16: 522-530, 2015.

76 Borghaei H, Paz-Ares L, Horn L, Spigel DR, Steins M, Ready NE, Chow LQ, Vokes EE, Felip E, Holgado E, Barlesi F, Kohlhäufl M, Arrieta O, Burgio MA, Fayette J, Lena H, Poddubskaya E, Gerber DE, Gettinger SN, Rudin CM, Rizvi N, Crinò L, Blumenschein Jr GR, Antonia SJ, Dorange C, Harbison CT, Graf Finckenstein F and Brahmer JR: Nivolumab versus docetaxel in advanced nonsquamous Non-Small-Cell Lung Cancer. N Engl J Med 373: 1627-1639, 2015.

77 Brahmer J, Reckamp KL, Baas P, Crinò L, Eberhardt WEE, Poddubskaya E, Antonia S, Pluzanski A, Vokes EE, Holdado E, Waterhouse D, Ready N, Gainor J, Arén Frontera O, Havel L, Steins M, Garassino MC, Aerts JG, Domine M, Paz-Ares L, Reck M, Baudelet C, Harbison CT, Lestini B and Spigel DR: Nivolumab versus docetaxel in advanced squamous-cell NonSmall-Cell Lung Cancer. N Engl J Med 373: 123-135, 2015.

78 Robert C, Long GV, Brady B, Dutriaux C, Maio M, Mortier L, Hassel JC, Rutkowski P, McNeil C, Kalinka-Warzocha E, Savage KJ, Hernberg MM, Lebbé C, Charles J, Mihalcioiu C, Chiarion-Sileni V, Mauch C, Cognetti F, Arance A, Schmidt H, 
Schadendorf D, Gogas H, Lundgren-Eriksson L, Horak C, Sharkey B, Waxman IM, Atkinson V, and Ascierto PA: Nivolumab in previously untreated melanoma without BRAF mutation. N Engl J Med 372: 320-330, 2015.

79 Motzer RJ, Escudier B, McDermott DF, George S, Hammers HJ, Srinivas S, Tykodi SS, Sosman JA, Procopio G, Plimack ER, Castellano D, Choueiri TK, Gurney H, Donskov F, Bono P, Wagstaff J, Gauler TC, Ueda T, Tomita Y, Schutz FA, Kollmannsberger C, Larkin J, Ravaud A, Simon JS, Xu L-A, Waxman IM, and Sharma P, for the CheckMate 025 Investigators: Nivolumab versus everolimus in advanced renalcell carcinoma. N Engl J Med 373: 1803-1813, 2015.

80 Garon EB, Rizvi NA, Hui R, Leighl N, Balmanoukian AS, Eder JP, Patnaik A, Aggarwal C, Gubens M, Horn L, Carcereny E, Ahn M-J, Felip E, Lee J-S, Hellmann MD, Hamid O, Goldman JW, Soria J-C, Dolled-Filhart M, Rutledge RZ, Zhang J, Lunceford JK, Rangwala R, Lubiniecki GM, Roach C, Emancipator $\mathrm{K}$ and Gandhi $\mathrm{L}$ for the KEYNOTE-001 Investigators: Pembrolizumab for the treatment of Non-SmallCell Lung Cancer. N Engl JMed 372: 2018-2028, 2015.

81 Powles T, Eder JP, Fine GD, Braiteh FS, Loriot Y, Cruz C, Bellmunt J, Burris HA, Petrylak DP, Teng S-1, Shen X, Boyd Z, Hegde PS, Chen DS and Vogelzang NJ: MPDL3280A (antiPD-L1) treatment leads to clinical activity in metastatic bladder cancer. Nature 515: 558-562, 2014.

82 Muro K, Chung HC, Shankaran V, Geva R, Catenacci D, Gupta S, Eder JP, Golan T, Le DT, Burtness B, McRee AJ, Lin C-C, Pathiraja K, Lunceford J, Emancipator K, Juco J, Koshiji M and Bang Y-J: Pembrolizumab for patients with PD-L1-positive advanced gastric cancer (KEYNOTE-012): a multicentre, openlabel, phase 1b trial. Lancet Oncol 17: 717-726, 2016.

83 Antonia SJ, López-Martin JA, Bendell J, Ott PA, Taylor M, Eder JP, Jäger D, Pietanza MC, Le DT, de Braud F, Morse MA, Ascierto PA, Horn L, Amin A, Pillai RN, Evans J, Chau I, Bono P, Atmaca A, Sharma P, Harbison CT, Lin C-S, Christensen O and Calvo E: Nivolumabalone and nivolumab plus ipilimumab in recurrent small-cell lung cancer (CheckMate 032): a multicentre, open-label, phase 1/2 trial. Lancet Oncol 17: 883-895, 2016.

84 Nghiem PT, Bhatia S, Lipson EJ, Kudchadkar RR, Miller NJ, Annamalai L, Berry S, Chartash EK, Daud A, Fling SP, Friedlander PA, Kluger HM, Kohrt HE, Lundgren L,Margolin K, Mitchell A, Olencki T, Pardoll DM, Reddy SA, Shantha EM, Sharfman WH, Sharon E, Shemanski LR, Shinohara MM, Sunshine JC, Taube JM, Thompson JA, Townson SM, Yearley JH, Topalian SL and Cheever MA: PD-1 blockade with pembrolizumab in advanced Merkel-cell carcinoma. N Engl JMed 374: 2542-2552, 2016

85 Vonderheide RH, LoRusso PM, Khalil M, Gartner EM, Khaira D, Soulieres D, Dorazio P, Trosko JA, Rüter J, Mariani GL, Usari T and Domchek SM: Tremelimumab in combination with exemestane in patients with advanced breast cancer and treatmentassociated modulation of inducible costimulatory expression on patient T cells. Clin Cancer Res 16: 3485-3494, 2010.

86 Rugo HS, Delord J-P, Im S-A, Ott PA, Piha-Paul SAA, Bedard PL, Sachdev J, Le Tourneau C, van Brummelen E, Varga A, Saraf S, Pietrangelo D, Karantza V and Tan A: Preliminary efficacy and safety of pembrolizumab (MK-34750) in patients with PD-L1-positive, estrogen receptor-positive (ER+)/ HER2negative advanced breast cancer enrolled in KEYNOTE-028. San Antonio Breast Cancer Symposium S5-07, 2015.
87 Nanda R, Chow LQM, Dees EC, Berger R, Gupta S, Geva R, Pusztai L, Pathiraja K, Aktan G, Cheng JD, Karantza V and Buisseret L: Pembrolizumab in patients with advanced triplenegative breast cancer: Phase Ib KEYNOTE -012 study. J Clin Oncol 34: 2460-2467, 2016.

88 Dirix LY, Takacs I, Nikolinakos P, Jerusalem G, Arkenau H-T, Hamilton EP, von Heydebreck A, Grote H-J, Chin K and Lippman ME: Avelumab (MSB0010718C), an anti-PD-L1 antibody, in patients with locally advanced or metastatic breast cancer: A phase Ib JAVELIN solid tumor trial. San Antonio Breast Cancer Symposium S1-04, 2015.

89 Gibson J: Anti-PD-L1 for metastatic triple-negative breast cancer. Lancet Oncol 16: e264, 2015.

90 Postow MA, Chesney J, Pavlick AC. Robert C, Grossmann K, McDermott D, Linette GP, Meyer N, Giguere JK, Agarwala SS, Shaheen M, Ernstoff MS, Minor D, Salama AK, Taylor M, Ott PA, Rollin LM, Horak C, Gagnier P, Wolchok JD and Hodi FS: Nivolumab and ipilimumab versus ipilimumab in untreated melanoma. N Engl J Med 372: 2006-2017, 2015.

91 Curran MA, Montalvo W, Yagita H and Allison JP: PD-1 and CTLA-4 combination blockade expands infiltrating T cells and reduces regulatory $\mathrm{T}$ and myeloid cells within B16 melanoma tumors. Proc Natl Acad Sci USA 107: 4275-4280, 2010.

92 Beavis PA, Milenkovski N, Henderson MA,John LB, Allard B, Loi S, Kershaw MH, Stagg J and Darcy PK: Adenosine Receptor 2A blockade increases the efficacy of anti-PD-1 through enhanced antitumor T-cell responses. Cancer Immunol Res 3: 506-517, 2015.

93 Allard B, Pommey S, Smyth MJ and Stagg J: Targeting CD73 enhances the antitumor activity of anti-PD-1 and anti-CTLA-4 mAbs. Clin Cancer Res 19: 5626-5635, 2013.

94 Hauser RA, Olanow CW, Kieburtz KD, Pourcher E, DocuAxelerad A, Lew M, Kozyolkin O, Neale A, Resburg C, Meya $\mathrm{U}$, Kenney C and Bandak S:Tozadenant (SYN115) in patients with Parkinson's disease who have motor fluctuations on levodopa: a phase $2 \mathrm{~b}$, double-blind, randomized trial. Lancet Neurol 13: 767-776, 2014.

95 Loi S, Pommey S, Haibe-Kains B, Beavis PA, Darcy PK, Smyth MJ and Stagg J: CD73 promotes anthracycline resistance and poor prognosis in triple-negative breast cancer. Proc Natl Acad Sci USA 110: 11091-11096, 2013.

96 Beavis PA, Slaney CY, Milenkovski N, Henderson MA, Loi S, Stagg J, Kershaw MH and Darcy PK: CD73: A potential biomarker for anti-PD-1 therapy. OncoImmunol 4: e1046675, 2015.

97 Müller P, Kreuzaler M, Khan T, Thommen DS, Martin K, Glatz K, Savic S, Harbeck N, Nitz U, Gluz O, von Bergwelt-Baildon M, Kreipe H, Reddy S, Christgen $M$ and Zippelius A: Trastuzumab emtansine (T-DM1) renders HER+ breast cancer highly susceptible to CTLA-4/PD-1 blockade. Sci Transl Med 7: 315ra188, 2015.

98 Yang W, Bai Y, Xiong Y, Zhang J, Chen S, Zheng X, Meng X, Li L, Wang J, Xu C, Yan C, Wang L, Chang CCY, Chang T-Y, Zhang T, Zhou P, Song B-L, Liu W, Sun S-c, Liu X, Li B-1 and $\mathrm{Xu} C$ : Potentiating the antitumour response of $\mathrm{CD} 8^{+} \mathrm{T}$ cells by modulating cholesterol metabolism. Nature 531: 651-655, 2016.

99 Emans L, Adams S, Loi S, Schmid P, Schneeweiss A, Rugo H, Chui $S$ and Winer E: A phase III randomized trial of atezolizumab in combination with nab-paclitaxel as first line therapy for patients with metastatic triple-negative breast cancer. Cancer Res 76(Suppl 4): OT1-01-06, 2016. 
100 Binder DC, Fu Y-X and Weichselbaum RR: Radiotherapy and immune checkpoint blockade: potential interactions and future directions. Trends Mol Med 21: 463-465, 2015.

101 Seyedin SN, Tang C and Welsh JW: Author's view: radiation and immunotherapy as systemic therapy for solid tumors. OncoImmunol 4: e986402, 2015.

102 Tang C, Wang X, Soh H, Seyedin S, Cortez MA, Krishnan S, Massarelli E, Hong D, Naing A, Diab A, Gomez D, Ye H, Heymach J, Komaki R, Allison JP, Sharma P and Welsh JW: Combining radiation and immunotherapy: A new systemic therapy for solid tumors? Cancer Immunol Res 2: 831-838, 2014.

103 Formenti SC and Demaria S: Combining radiotherapy and cancer immunotherapy: a paradigm shift. J Natl Cancer Inst 105: 256-265, 2013.

104 Parmiani G, Maccalli C and Maio M: Integrating immune checkpoint blockade with anti-neo/mutated antigens reactivity to increase the clinical outcome of immunotherapy. Vaccines 3: 420-428, 2015

105 Hodi FS, O'Day SJ, McDermott DF, Weber RW, Sosman JA, Haanen JB, Gonzalez R, Robert C, Schadendorf D, Hassel JC, Akerley W, van den Eertwegh AJ, Lutzky J, Lorigan P, Vaubel JM, Linette GP, Hogg D, Ottensmeier CH, Lebbé C, Peschel C, Quirt I, Clark JI, Wolchok JD, Weber JS, Tian J, Yellin MJ, Nichol GM, Hoos A and Urba WJ: Improved survival with ipilimumab in patients with metastatic melanoma. N Engl J Med 363: 711-723, 2010.

106 Koyama S, Akbay EA, Li YY, Herter-Sprie GS, Buczkowski KA, Richards WG, Gandhi L, Redig AJ, Rodig SJ, Asahina H, Jones RE, Kulkarni MM, Kuraguchi M, Palakurthi S, Fecci PE, Johnson BE, Janne PA, Engelman JA, Gangadharan SP, Costa DB, Freeman GJ, Bueno R, Hodi FS, Dranoff G, Wong K-K and Hammerman PS: Adaptive resistance to therapeutic PD-1 blockade is associated with up-regulation of alternative immune checkpoints. Nat Commun 7: 10501, 2016.

107 Curti BD, Kovacsovics-Bankowski M, Morris N, Walker E, Chisholm L, Floyd K, Walker J, Gonzalez I, Meeuwsen T, Fox BA, Moudgil T, Miller W, Haley D, Coffey T, Fisher B, Delanty-Miller L, Rymarchyk N, Kelly T, Crocenzi T, Bernstein E, Sanbom R, Urba WJ and Weinberg AD: OX40 ia a potent immune-stimulating target in late-stage cancer patients. Cancer Res 73: 7189-7198, 2013.
108 Faget J, Bendriss-Vermare N, Gobert M, Durand I, Olive D, Biota C, Bachelot T, Treilleux I, Goddard-Leon S, Lavergne E, Chabaud S, Blay JY, Caux C and Ménétrier-Caux C: ICOSLigand expression on plasmacytoid dendritic cells supports breast cancer progression by promoting the accumulation of immunosuppressive CD4+ T cells. Cancer Res 72: 6130-6141, 2012.

109 Voutsadakis IA: The network of pluripotency, epithelial mesenchymal transition and prognosis of breast cancer. Breast Cancer: Targets Ther 7: 303-319, 2015.

110 Reim F, Dombrowski Y, Ritter C, Buttmann M, Häusler S, Ossadnik M, Krockenberger M, Beier D, Beier CP, Dietl J, Becker JC, Hönig A and Wischhusen J: Immunoselection of breast and ovarian cancer cells with trastuzumab and Natural Killer cells: Selective escape of CD44high/CD24low/HER2 low breast cancer stem cells. Cancer Res 69: 8058-8066, 2009.

111 Santisteban M, Reiman JM, Asiedu MK, Behrens MD, Nassar A, Kalli KR, Haluska P, Ingle JN, Hartmann LC, Manjili MH, Radisky DC, Ferrone $S$ and Knutson KL: Immune-induced Epithelial to Mesenchymal Transition in vivo generates breast cancer stem cells. Cancer Res 69: 2887-2895, 2009.

112 Noh KH, Lee Y-H, Jeon J-H, Kang TH, Mao C-P, Wu T-C and Kim TW: Cancer vaccination drives Nanog-dependent evolution of tumor cells toward an immune-resistant and stemlike phenotype. Cancer Res 72: 1717-1727, 2012.

113 Di Tomaso T, Mazzoleni S, Wang E, Sovena G, Clavenna D, Franzin A, Mortini P, Ferrone S, Doglioni C, Marincola FM, Galli R, Parmiani $G$ and Maccalli C: Immunobiological characterization of cancer stem cells isolated from glioblastoma patients. Clin Cancer Res 16: 800-813, 2010.

$114 \mathrm{Ma} \mathrm{W}$, Gilligan BM, Yuan J and Li T: Current status and perspectives in translational biomarker research for PD-1/PDL1 immune checkpoint blockade therapy. J Hematol Oncol 9: 47, 2016.
Received August 3, 2016

Revised August 19, 2016 Accepted August 22, 2016 